\title{
Traversing the spaces of higher education through writing
}

Author:
Laura M. Drennan ${ }^{1}$
Affiliation:
${ }^{1}$ Unit for Academic Literacy,
Centre for Teaching and
Learning, University of the
Free State, South Africa
Corresponding author:
Laura Drennan,
drennanl@ufs.ac.za
Dates:
Received: 04 Nov. 2015
Accepted: 07 Mar. 2017
Published: 24 Apr. 2017
code with your
How to cite this article:
Drennan, L.M., 2017 on
'Traversing the spaces of
higher education through
writing', Reading \& Writing
8(1), a126. https://doi.
org/10.4102/rw.v8i1.126
Read online:
Copyright:
@ 2017. The Authors.
Licensee: AOSIS. This work
is licensed under the
Creative Commons
Attribution License.

Writing functions as an important tool that spans various spaces in higher education. Moving away from a 'skills approach' to writing, this article argues that the writing centre serves as an intermediary between students and academic lecturers. The article discusses how the current practices at the writing centre promotes the development of writing as a key construct that spans a number of spaces in higher education. The article draws on the collaborative initiatives with two different disciplines. The data collection on stakeholders' responses indicates that a more structured, purposeful writing-intensive approach needs to be undertaken within the disciplines in order to address institutional objectives of access and success in higher education.

\section{Introduction}

This article is written from the perspective that writing is an important tool that traverses several spaces in higher education. Drawing on the collaborative efforts between the writing centre and disciplinary experts, the article looks at how current writing centre practices move towards facilitating the development of academic writing, which traverses these various higher educational spheres. Advocating an academic literacies approach, the article discusses the role of writing within the social space, the space of academic citizenship, as well as the merging physical, teaching and learning spaces.

\section{The social space}

Contrary to popular misconception, writing is not a discrete skill that can be taught in isolation and merely applied across disciplines (Archer 2010; Clarence 2012b). The act of writing is more complex than this. Writing is a central process through which students learn new subject content and gain discipline-specific knowledge (Lea \& Street 1998:158). Each discipline is a social space within which students need to learn and master the unique 'ways of understanding, interpreting and organizing knowledge' (Lea \& Street 1998:158) in a particular discipline, referred to as Discourse (Gee 2001). In order for students to become members of a particular community of knowledge, they are expected to become proficient in that particular discourse.

The assumption that writing is a generic skill that can be transferred is based on the idea that the conventions of academic writing at university are standard (Clarence 2012b). However, language and activities are determined by a particular community of knowledge (Hyland 2002; Strevens 1988), so too are the 'conventions' of writing discipline-specific. Moreover, the writing conventions within the social spaces of various disciplines are also contested among the various stakeholders: the university as an institution, academic staff members and students (Lea \& Street 1998). These stakeholders have different expectations and interpretations of university writing.

Clarence (2012b:128) is in agreement that writing is part of a contested social space, where 'writing itself is part of negotiating and constituting that space'. Within this contested space, there are three primary perspectives of student writing within higher education, essentially encapsulating one another: 'study skills', 'academic socialisation' and 'academic literacies' (Clarence 2012b; Lea \& Street 1998; Street 1997). Lea and Street (2006) define these perspectives as follows. Firstly, the study skills approach requires that students acquire a number of skills that can be applied in other subject areas. This view maintains that low proficiency that can be rectified by means of addressing various surface language features. Secondly, the academic socialisation perspective involves 'socialising' the student into the 'culture' of a particular community of knowledge. However, one of the problems underlying this approach is the assumption that students need to be taught the customs and practices of a 'relatively homogenous culture' pertaining to academe (Lea \& Street 1998:159). The third perspective, the approach advocated in this article, is that of 'academic literacies'. This approach is concerned with notions of discourse and power, where students are 
required to be aware of numerous communicative practices to the extent that they are able to switch between practices, depending on the setting. The academic literacies perspective maintains that writing is part of a process of negotiating meaning rather than acquiring a set of skills necessary for success in higher education studies (Lea \& Street 1998:159). This article supports this approach, because it aligns with the view that literacies are discipline-specific and that students need to be equipped with the skills that allow them to function within and become a member of a particular discourse. Lillis (2001) does, however, point out that these various perspectives coexist within the same pedagogic scope, with various higher education stakeholders advocating different perspectives, thereby contributing to the contested nature of this social space.

\section{The space of academic citizenship}

Writing practices are also used to control access to higher education, where 'access' students struggle to be acknowledged as legitimate students (Burke 2008). They are often viewed as lacking 'real' academic literacy and therefore have to work towards assuming an alternative position in the academy (Van Rensburg 2011). In order to become an accepted member of a particular community of knowledge and be seen as a respected 'academic voice' that 'resonates with other "voices"' (Burke 2008:199), these students need to develop and establish their own voice. In this way, writing can also be seen as being a constituent of the space of academic citizenship. Burke (2008:200) clearly articulates the link between writing, higher education as a contested social space and the space of academic citizenship: 'Writers are socially situated subjects and the meanings they produce through their writing are constituted through the contested and multiple discourses at play in different social fields'.

The notion of academic citizenship raises concerns about epistemological access, particularly in the case of 'access' students. The new South African educational policy [Department of Higher Education and Training (DHET) White Paper 2013] advocates the widening of access to tertiary institutions in an attempt to accommodate students entering higher education from disadvantaged backgrounds. The majority of 'access' students are second-language learners who come from a schooling system that has not adequately provided them with the essential learning experiences, concepts and schemas necessary for success within higher education (Thesen \& Van Pletzen 2006).

Despite these challenges, higher education institutions are still expected to ensure that students meet the required course and content goals in their studies. This is challenging because many students do not possess the critical literacy skills in order to succeed at university, as a result of inadequate prior learning. The term literacy refers to fluency in the particular discourse of a field of study; while discourse refers to the way in which language is used in a particular community of knowledge so that one can 'identify oneself as a member of a socially meaningful group or "social network"
(Boughey 2002:296; Gee 1990). In terms of literacy, one of the key skills necessary for success in higher education is critical thinking, which requires that students define their 'own beliefs in the context of existing knowledge' (Baxter Magolda 2003:232), as a trademark of an educated person is this sense of self and the facility to apply knowledge in various contexts. Critical thinking, therefore, involves students becoming aware of their principal role in the production of knowledge. Students need to make a shift from merely accepting knowledge from authorities in their field of study to constructing it for themselves (Baxter Magolda 2003). In order then for a student to become an accepted member of a particular discourse and a recognised citizen of the academy, tertiary institutions need to make an asserted effort to develop students' critical thinking skills as a core skill in shaping students' academic literacies (Lea 1999; Lea \& Street 2000).

Various movements, such as writing-across-the-curriculum (Bohr et al. 2016; Condon \& Rutz 2012; McLeod \& Soven 1992; Young 2003) and writing-in-the-discipline (WID) (Bean 2011; Condon \& Rutz 2012), advocate writing as a tool to promote critical thinking as a means to empower students. The former movement supports the notion that students 'write to learn', where writing facilitates deep-level learning of course content. WID involves developing students' ability to write within a particular discipline, familiarising them with discipline-specific writing conventions (Bean 2011). Writing is essentially an instrument for thinking, thus the communication of ideas and writing feature in all disciplines in higher education. Writing is used to develop the facilities and proficiencies most valued in various disciplines (Condon \& Kelly-Riley 2004). Rivard (1994:970) recognises the importance of writing as a process, 'not only for learning about something or acquiring knowledge, but for generating a personal response to something, for clarifying ideas, and for constructing knowledge'.

Rivard (1994) argues that critical thinking is key in producing students who are lifelong learners, one of the primary objectives of education. In order to improve student writing, their abilities as thinkers need to be addressed. They should be challenged to use knowledge towards authentic problem solving and towards integrating new information with existing knowledge (Rivard 1994:970). In this vein, Burke (2008:199) postulates that writing serves to offer students opportunities to explore various ideas and combine them towards understanding and internalising numerous concepts and experiences being explored in their studies.

The development of critical thinking can be achieved by means of providing students with sufficient opportunities to stimulate their thinking, integrate ideas and essentially improve both their thinking and writing skills (Tsui 2002). In order to provide students with opportunities, instead of emphasising the finished product of writing, educators need to focus on the process of writing and the skills this fosters. Writing functions as an 'important tool for thinking and learning about disciplinary content, as well as a 
necessary means of assessing content knowledge' (Clarence 2012a). By means of writing and rewriting, as well as providing students with constructive feedback with which they are required to engage, students are guided to reflect critically on their performance and development (Tsui 2002:748). Such an approach, however, requires much commitment and time on the part of academic staff. Providing students with constructive feedback on their writing assignments in addition to teaching content is very time consuming. Furthermore, it requires that content lecturers take responsibility for and cognisance of the literacy needs of individual students and that they are familiar with pedagogy and methodology of academic literacy necessary to address these needs.

\section{The merging physical, teaching and learning spaces}

The writing centre as a physical space in South Africa was conceptualised to address the challenge of academic literacy among historically disadvantaged students in higher education. Writing centres are expected to take cognisance of a number of factors. These include the predominantly second-language (L2) nature of the tertiary education scene at many higher education institutions and that many of these students' prior learning is not as it should be. This is particularly the case for those from disadvantaged communities. Another factor that needs consideration is the necessity for students to acquire discipline-specific discourses (Archer 2010:496).

Writing is one of the principal means of assessment in higher education. Addressing students' writing needs is therefore linked to promoting student access and success in higher education (Archer 2008). The writing centre faces several challenges within this context. One of these is the perception that the writing centre serves as a remedial centre where students' language 'deficiencies' can be 'fixed' (Archer 2010), thereby functioning as an extension to existing academic development initiatives (Archer 2012). This perspective is grounded in the 'study skills' view of student writing, which maintains that writing constitutes a number of atomised skills that can be taught in isolation and applied across the curriculum (Clarence 2012a; Lillis 2001; Street 2004). Another issue, linked to this perspective, is that students do not visit the writing centre as often as necessary to develop their academic writing skills. Writing should be acknowledged as a process that requires several drafting sessions geared towards fostering students' critical thinking, as well as the acquisition of course content and skills necessary for success in their studies. The core function of a writing centre should be the development of 'better writers, not better writing' (Boquet \& Lerner 2015:170). The sporadic, once-off attendance of sessions at the writing centre makes it very difficult to rigorously measure the effect of writing centre initiatives.

A reasonable response to these challenges is to work towards changing the perception of the function of the writing centre. Instead of a 'fix-it shop', the writing centre should be viewed as an intermediary between students and lecturing staff. The writing centre is in a position to address aspects of teaching and research that are difficult to achieve in classrooms (Boquet \& Lerner 2015). The one-on-one service provides students with opportunities to discuss and negotiate meaning, in accordance with the academic literacies approach to student writing. Content lecturers and tutors might know what kind of writing is expected in their particular field, but they are often unable to isolate the particular writing conventions of the disciplinespecific discourse and communicate these to students (Clarence 2012a; Lillis \& Turner 2001). Boughey (2005:287) asserts that by making the rules and conventions regarding what 'count[s] as knowledge', the great divide between student and lecturers could be bridged. The writing centre can serve as a mediator in bridging this gap, thereby assisting institutional objectives of access and success.

A feasible route to take regarding the work done by the writing centre is one of close collaboration between writing centre practitioners and the content lecturers in the disciplines. The following initiatives are representative of the partnership between lecturing staff and writing centre practitioners towards addressing the discipline-specific writing needs of tertiary students.

\section{Collaborative initiatives}

The following section describes collaborative initiatives with the Medical Faculty and the Philosophy department. In each case, the nature of the collaboration as well as various stakeholder perspectives on the initiatives will be discussed.

\section{Collaboration with the Medical Faculty}

\section{Nature of collaboration}

The writing centre worked with academic staff from the Medical Faculty towards improving first-year medical students' critical reflective writing skills. Students were expected to write critical reflective essays based on their experiences of a group visit to local clinics. The assignment instructions required that students address certain prompts with regard to the three stages of critical reflection.

Three contact sessions were scheduled for these students. The first was a general presentation on critical reflective writing to a group of 80 students, which was compulsory. Students worked independently to answer certain questions geared towards creating awareness about critical reflection, followed by feedback in the plenary. The second intervention was a compulsory, tailor-made workshop during which students were divided into five groups of 20 . The goal behind the smallgroup workshops was to facilitate student engagement with discipline-specific workshop materials that were generated specifically to help students unpack the assignment topic and address various prompts they had selected to answer. The materials were designed explicitly to help students address three components of critical reflection that were outlined in the assessment rubric provided by the Medical Faculty, as the content lecturer had highlighted students' inability to 
distinguish between the kinds of information required for each stage of the critical reflective process. Genuine student responses from previous years' submissions informed the design of the materials to assist students to unpack the process. Students shared their experiences and ideas during the smallgroup workshops, discussing and negotiating where to place certain components of information within the reflective framework. The final intervention constituted voluntary individual sessions with a writing consultant at the writing centre, where the consultant assisted students with their individual writing needs pertaining to the assignment.

The following excerpts from the small-group workshop materials illustrate how activities were scaffolded to allow students to explore and unpack various ideas, merge them towards comprehending and internalising their own experiences and finally construct knowledge for themselves in a personal response (Burke 2008; Craft 2005; Rivard 1994).

Example: What was special about the clinic visit?

- What? (The facts)

I spoke to the patients who were waiting and asked them some questions.

- So what? (My interpretation)

I could see that they were genuinely suffering, that they appreciated my taking an interest in them and that they were grateful.

- Now what? (What did I learn from this?)

It requires a little effort on my part to mean something to someone. When I am a doctor one day, I am going to make an asserted effort never forget to see my patients as people.

Activity - Group work: Work in pairs to answer the following questions. Talk to your partner about the answer you would give to the following questions, and then write down your response:

- What did you learn that you did not know before (about yourself, your fellow students, the people at the clinic, the services that are available)? Here you need to demonstrate thoughtfulness about the learning experience in terms of what happened or what you experienced ('what?').

- Now think about how your original assumptions are challenged with regard to this prompt ('so what?').

- Think about what you have learned from this experience (pertaining to the prompt) and what it could mean for your future ('now what?').

\section{Student perspectives}

Of the 80 students registered for the medical course, 52 consented to complete the workshop evaluation questionnaire after the small-group interventions. The questionnaire comprised two divisions: a demographic section consisting of nine single-option, multiple-choice questions, followed by a section evaluating the efficacy of the workshop materials. Questions in this section included whether students found the workshop helpful, whether they understood the assignment topic better after the workshop, whether they better understand the required structure of the assignment in question and whether they consider such writing workshops necessary for approaching writing tasks. The final six questions were open-ended, briefly requesting students to comment on what they liked and did not like about the workshop and whether they still felt uncertain about something that was covered in the workshop.

The following figures illustrate student perspectives regarding whether the workshop aided their understanding of the assignment topic (Figure 1), whether they better understood the required structure of the assignment in question (Figure 2) and whether they deemed such workshops necessary towards the approach taken to writing tasks (Figure 3).

The majority (94\%) of students' responses indicated that they found the small-group workshops helpful in terms of their understanding of the assignment topic and $98 \%$ of students indicated that the workshop helped them understand the required assignment structure. The majority (96\%) also stated that they deem such workshops necessary towards the approach of assignments in their discipline.

Students' open-ended responses on the evaluation form demonstrate how students appreciated the opportunity to hear the views of others. Critical reflection is used to encourage students to discover different ideas so that they broaden their perspectives and work towards constructing knowledge for themselves (Baxter Magolda 2003; Bean 2011;

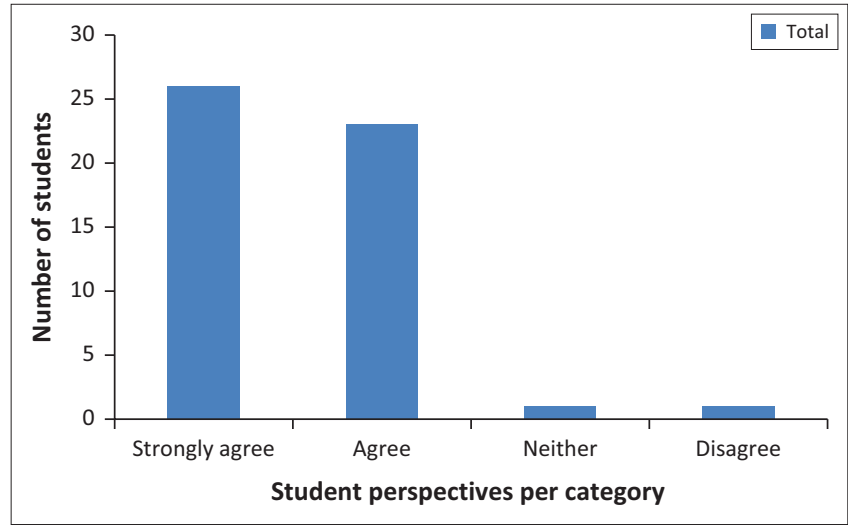

FIGURE 1: Post-workshop understanding of the assignment topic.

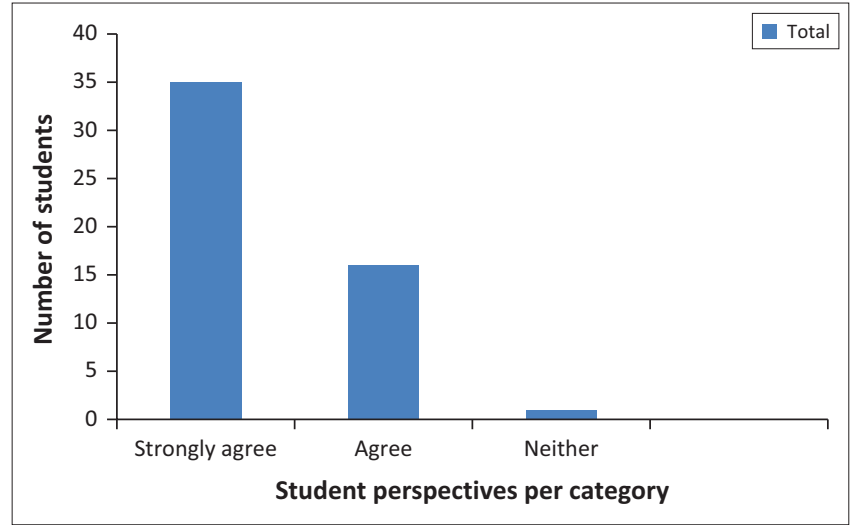

FIGURE 2: Post-workshop understanding of the required assignment structure. 


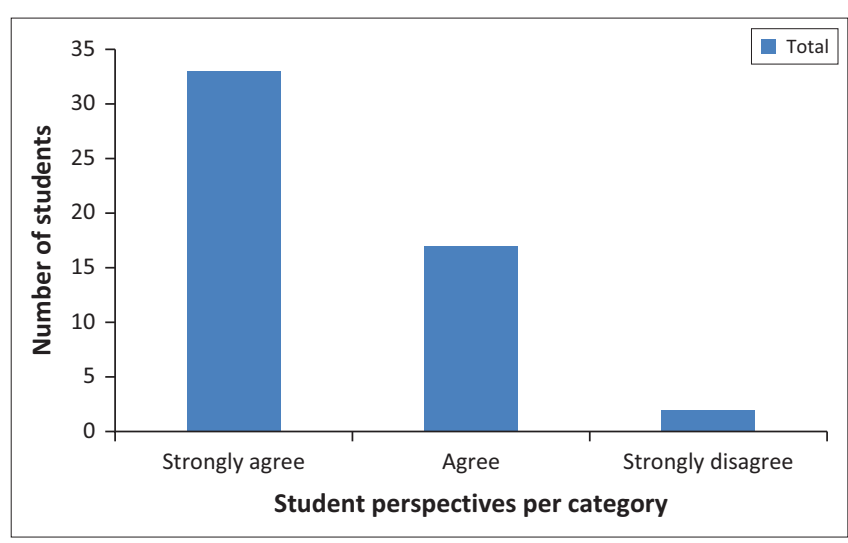

FIGURE 3: Necessity of workshops to assist students' approach to assignments.

Lea \& Street 2000; Mezirow 1990) and developing their authentic voice. This sort of academic experience supports students' alignment of new information with existing knowledge, thereby promoting deep-level learning and internalisation of key constructs and experiences.

Students said that they:

'enjoyed consulting with [their] peers about ideas'

and enjoyed:

'the interaction between [students] and the lecturer'.

Students commented that:

'the [writing] consultant was very engaging, helping [them] to gain perspective'.

Similarly, one student remarked that:

'the discussion made [them] aware of different ideas and it made [them] look at the task from a different perspective'.

Another student commented that the workshop presented the: 'opportunity to stop and think first, and also to [ask] any questions'.

After participating in three different writing interventions hosted by the writing centre, students' critical reflective assignments were assessed by their content lecturer. The Medical Department marked students' work using a rubric designed specifically for the critical reflective essay by the content lecturer. The assessment criteria constituted five sections. The first component tested students' ability to interpret the purpose and importance of reflection; the second tested self-growth and development; and the third assessed the impact on learning. These three components were labelled 'what?', 'so what?' and 'now what?', respectively. The last two criteria were mechanics and structure, and overall impression of the assignment. The rubric included two sections for the assessment of standard or level one for the student to self-assess and the second for the content lecturer's assessment, graded according to a fourpoint system. Four points were awarded for 'superior' work, three for an 'adequate' submission, two points for 'minimal' effort and one point for an 'inadequate' response.

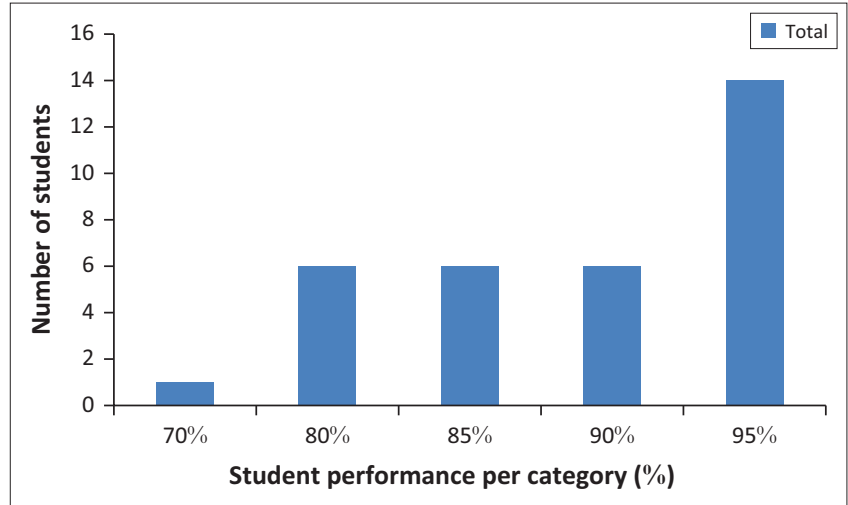

FIGURE 4: Medical students' performance on critical reflective essay (\%).

Figure 4 shows the percentages scored by students on their reflective essays. Of the total cohort of 80 students, 34 students attended individual sessions, 33 of whom received distinctions for their final submissions to their content lecturer.

\section{Collaboration with the Philosophy Department}

\section{Nature of collaboration}

The work with the Philosophy Department is exemplary of inter-disciplinary collaborative partnerships. The content lecturer was very eager to employ second-language teaching methodology in his content classes in order to improve students' performance in the course. There was much discussion and collaboration with regard the specific writing needs of the Philosophy students. The feedback received from students and the content lecturer was used to inform and improve on the development of workshop materials for this particular cohort. For example, after the very first collaborative intervention with this department, it became clear that students did not understand the assignment prompt clearly. This resulted in much discussion between the content lecturer and writing centre practitioners around the formulation of assignments and test questions to accommodate the literacy needs of students in the course, the majority of whom were second-language learners of English. Furthermore, student and writing consultant feedback also indicated that students found the texts in the course very difficult and they struggled to understand the course content as a result. The lecturer was advised to focus particularly on promoting students' access and comprehension of key texts in the course. Compulsory comprehension tests based on prescribed reading allocated to students were then introduced into the course.

One of this content specialist's primary concerns was students' inability to answer essay-type questions. Writing workshop materials were developed for small-group sessions with the students, which focused particularly on answering the particular essay topic assigned for Philosophy. The materials were carefully scaffolded towards assisting students to respond to the assignment due in the course, incorporating genuine Philosophy students' sample responses from previous years to teach the principles of academic essay writing for the discipline. The workshop materials focused particularly on unpacking the assignment topic, the structure of the academic 
essay, the formulation of a good introductory paragraph and developing an argument in an essay. Following the writing workshops were compulsory individual sessions at the writing centre, during which consultants focused on students' individual writing needs.

The individual sessions at the writing centre were geared towards conversations around meaning making and promoting the development of students' own voice. Both the workshops and the individual sessions provided students with the opportunity to clarify their meaning, listen to the opinions of others and use these to stimulate their thinking and construct knowledge for themselves. The sessions furthermore provided students with constructive feedback that facilitated engagement and critical reflection.

\section{Stakeholder perspectives}

Of the 67 students registered for Philosophy, 55 completed the workshop evaluation form, the format of which was outlined in the previous case study. All 67 students attended at least one individual session at the writing centre after the workshop. The following responses to the open-ended questions on post-intervention evaluation forms serve to highlight student perspectives of the various writing interventions.

Regarding the focal points of the workshop materials, students commented that:

'[the workshop materials] test [their] understanding of the Topic to check where [students] are struggling';

in other words:

'[the workshop] broke down the topic into simpler words'.

Students said they liked:

'the explanation of [what] the structure of the assignment should [look like]'

and that they:

'liked the manner in which everything was explained with examples ... [that it made it] simpler to visualise and understand what is expected of [students in terms of their] assignment[s]'.

Students' gave very positive feedback concerning individual writing sessions at the writing centre. One student mentioned that:

everything was simplified and explained in a way that [they] could understand. The [writing consultant] took time to go through the assignment with [them] to [identify] errors and other things. It was really helpful.

\section{Other students commented that:}

'[they] are free and ... can ask when [they] don't understand, unlike in class when everyone is listening'

and that the consultant:

'focuses on the student'.
Students indicated that they liked the:

'intimate sessions [that are] not crowded'.

The individual sessions also provided opportunities for conversations around meaning making. Students:

'liked getting someone else's perspective and input ... and hearing different ideas'.

The one-on-one sessions created room for students to:

'address any concerns that [they] had about [their] assignment. [The session] allowed [for their writing] to be critically reviewed before final submission'.

Students seemed to enjoy:

'sharing [their] own views on how [they] understand the essay and the topic'.

As one student's feedback indicated, the occasions where students can negotiate meaning making regarding a particular assignment topic and how they understand it are rare.

Figures 5, 6 and 7 illustrate students' responses on postworkshop evaluation forms. Overall, students either agreed or strongly agreed that the workshop assisted in their understanding of the assignment topic and required format. Also, their answers demonstrate that they deem such writing workshops necessary for approaching assignment topics.

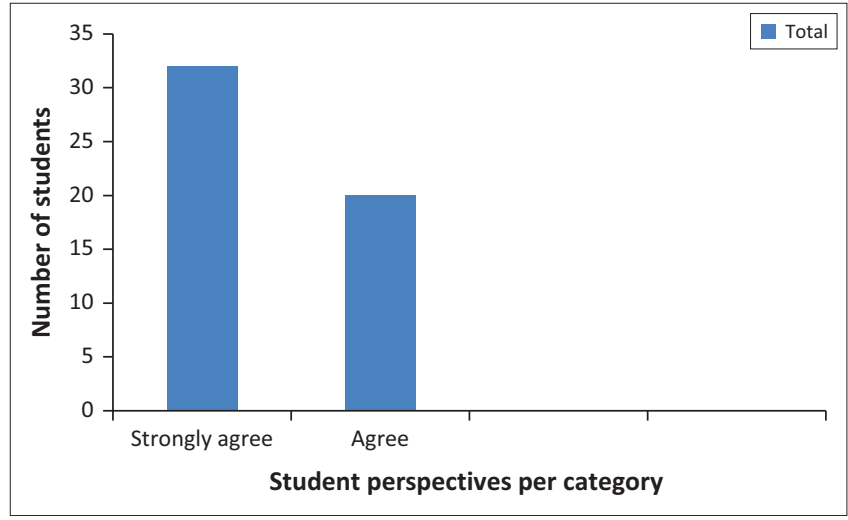

FIGURE 5: Post-workshop understanding of the assignment topic.

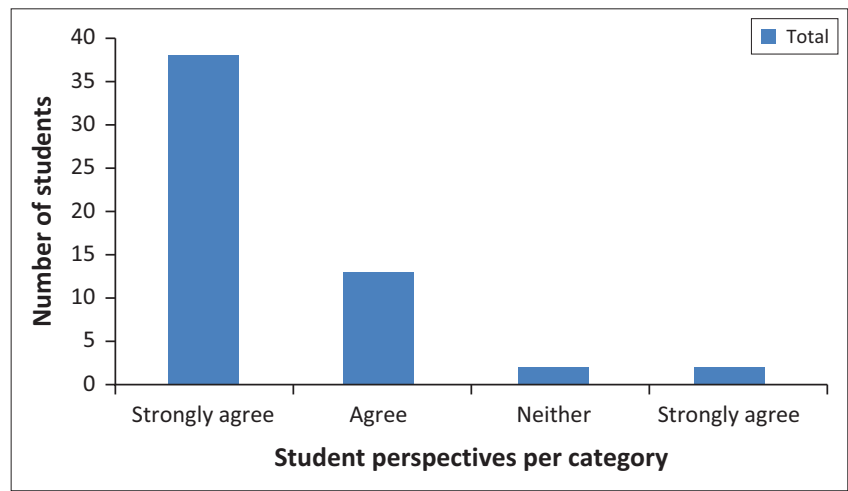

FIGURE 6: Post-workshop understanding of the required assignment structure. 


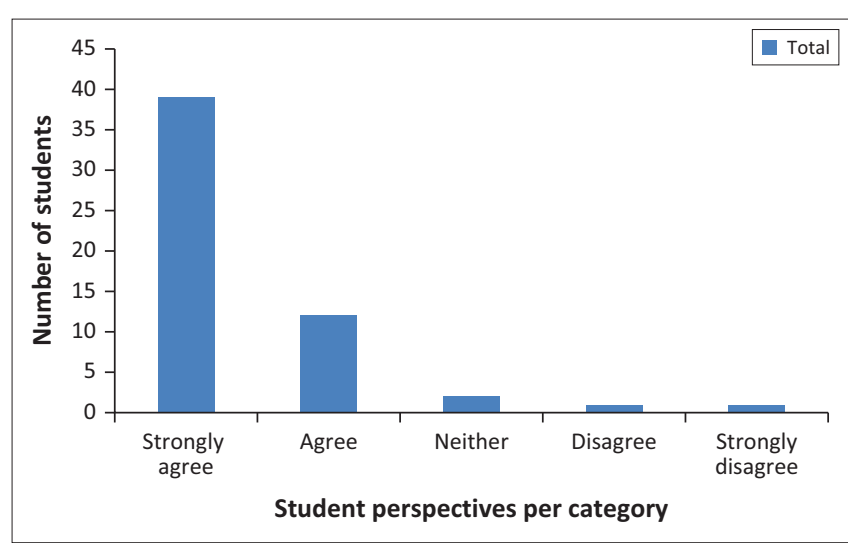

FIGURE 7: Necessity of workshops to assist students' approach to assignments.

The content lecturer provided feedback on students' performance in the course. He was very supportive of the writing initiatives for his students. He was of the opinion that the combination of his changed approach to teaching on the course with regard to accommodating second-language learners and the writing interventions presented by the writing centre, had a positive impact on students' performance. He reported that $46 \%$ of students obtained a score of between $50 \%$ and $74 \%$, and $41 \%$ of students obtained a distinction for the subject. Although it is difficult to determine to what extent the writing interventions, in particular, impacted on students' performance, given the change in the lecturer's approach to teaching as an additional factor, the students' results do support the assertion that very close collaboration between disciplinary experts and writing centre experts can prove promising for student access and success within higher education.

\section{Ethical consideration}

Students' right to privacy was respected with regard to the research conducted. No identifying information has been included in the paper. Furthermore, students consented to complete anonymous evaluations of the various interventions discussed in the article.

\section{Conclusion and recommendations}

The purpose of the article was to illustrate how the current practices at the writing centre promotes the development of writing as an important tool that straddles various spheres of higher education. Writing is not a generic skill that can be taught in decontextualised writing courses and transferred to the various subject areas. Instead, it serves as a tool to negotiate meaning and construct knowledge within various social spaces. In terms of the space of academic citizenship and epistemological access, the development of disciplinespecific writing skills is essential if students are to be acknowledged as respected members of specific communities of knowledge. Writing encourages the development of the facilities and proficiencies most valued in various disciplines.

The writing centre serves as a physical space that promotes the development of writing as a critical skill within these various spaces in tertiary education. By means of collaborative partnerships between writing centre practitioners and academic staff members, the writing centre can serve as an intermediary between content lecturers and students. The two collaborative initiatives investigated in the article were perceived positively and it appears that the interventions might have had a positive impact on students' writing performance, although it is very difficult to demonstrate the direct impact of such collaborative initiatives.

Such inter-disciplinary collaboration should be promoted and students' writing needs, regarding discourse-specific writing conventions, need to be studied further and in more depth. The identification and teaching of discipline-specific writing interventions can facilitate students' acquisition of and fluency in specialised discourses. In this way, writing centres can assist institutions in meeting the objective of addressing access and success within higher education.

\section{Acknowledgements Competing interests}

The author declares that she has no financial or personal relationship(s) that may have inappropriately influenced her in writing this article.

\section{References}

Archer, A., 2008, 'Investigating the effect of writing centre interventions on student writing', South African Journal of Higher Education 22(2), 210-226. https://doi. org/10.4314/sajhe.v22i2.25784

Archer, A., 2010, 'Challenges and potentials for writing centres in South African tertiary institutions', South African Journal of Higher Education 24(4), 495-510.

Archer, A., 2012, 'Changing academic landscapes: Principles and practices of teaching writing at the University of Cape Town', in C. Thaiss, G. Bräuer, P. Carlino, L. Ganobcsik-Williams \& A. Sinha (eds.), Writing programs worldwide: Profiles of academic writing in many places, pp. 353-364, Parlor Press, Anderson, $\mathrm{CO}$.

Baxter Magolda, M., 2003, 'Identity and learning: Student affairs' role in transforming higher education', Journal of College Student Development 44(2), 231-247. https://doi.org/10.1353/csd.2003.0020

Bean, J.C., 2011, Engaging ideas: The Professor's guide to integrating writing, critical thinking, and active learning in the classroom, Jossey-Bass, San Francisco, CA.

Bohr, D.J., Alusow Hart, S., Karaus, J., Finn, A., Hawkins, B. \& Stark, K., 2016, 'From theory into the classroom: Practical applications from writing across the curriculum', Paper Presented at the Student Success in Writing Conference, Rhoades, Georgia, 11th March. http://digitalcommons.georgiasouthern.edu/ Rhoades, Georgia,
sswc/2016/2016/20

Boquet, E.H. \& Lerner, N., 2015, 'After "the idea of a writing centre"', College English 71(2), 170-189.

Boughey, C., 2002, “'Naming' students” problems: An analysis of language-related discourses at a South African university', Teaching in Higher Education 7(3), 295307. https://doi.org/10.1080/13562510220144798

Boughey, C., 2005, “'Epistemological” access to the university: An alternative perspective', South African Journal of Higher Education 19(3), 230-242. https:// doi.org/10.4314/sajhe.v19i3.25516

Burke, J., 2008, 'Writing, power and voice: Access to and participation in higher education', Changing English: Studies in culture and education 15(2), 199-210. https://doi.org/10.1080/13586840802052419

Clarence, S., 2012a, 'Collaborative writing development with students and lecturers at the UWC Writing Centre', in A. Archer \& R. Richards (eds.), Changing spaces, pp. 59-72, African Sun Media, Stellenbosch.

Clarence, S., 2012b, 'Making inter-disciplinary spaces for talk about and change in student writing and literacy development', Teaching in Higher Education 17(2), 127-137. https://doi.org/10.1080/13562517.2011.611876

Condon, W. \& Kelly-Riley, D., 2004, 'Assessing and teaching what we value: The relationship between college-level writing and critical thinking abilities', Assessing Writing 9, 56-75. https://doi.org/10.1016/j.asw.2004.01.003

Condon, W. \& Rutz, C., 2012, 'A taxonomy of writing across the curriculum programs: Evolving to serve broader agendas', College Composition and Communication 64(2), 357-382. 
Craft, M.S., 2005, 'Reflective writing and nursing education', Journal of Nursing Education 44(2), 53-57.

Department of Higher Education and Training (DHET), 2013, White paper for postsecondary education and training: Building an expanded, integrated and effective post-school system, DHET, Pretoria.

Gee, J.P., 1990, Social linguistics and literacies: Ideology in discourses, Falmer, Basingstoke.

Gee, J.P., 2001, 'Reading as situated language: A sociocognitive perspective', Journal of Adolescent \& Adult Literacy 44(8), 714-725. https://doi.org/10.1598/JAAL.44.8.3

Hyland, K., 2002, 'Specificity revisited: How far should we go now?', English for Specific Purposes 21(4), 385-395. https://doi.org/10.1016/S0889-4906(01)00028-X

Lea, M.R., 1999, 'Academic literacies and learning in higher education: Constructing knowledge through texts and experiences', in C. Jones, J. Turner \& B. Street (eds.), Student writing in the University: Cultural and epistemological issues, pp. 103-124, John Benjamins Publishing Company, Amsterdam.

Lea, M.R. \& Street, B.V., 1998, 'Student writing in higher education: An academic literacies approach', Studies in Higher Education 23(2), 157-172.

Lea, M.R. \& Street, B.V., 2000, 'Student writing and staff feedback in higher education: An academic literacies approach', in M.R. Lea \& B. Stierer (eds.), Student writing in higher education: New contexts, pp. 32-46, The Society for Research into Higher Education \& Open University Press, Buckingham.

Lea, M.R. \& Street, B.V., 2006, 'The "Academic Literacies" model: Theory and applications', Theory Into Practice 45(4), 368-377.

Lillis, T.M., 2001, Student writing. Access, regulation, desire, Routledge, London.
Lillis, T. \& Turner, F., 2001, 'Student writing in Higher Education: Contemporary confusion, traditional concerns', Teaching in Higher Education 6(1), 57-68. https://doi.org/10.1080/13562510020029608

McLeod, S.H. \& Soven, M., 1992, Writing across the curriculum, Sage, Newbury Park, CA.

Mezirow, J., 1990, Fostering critical reflection in adulthood, Jossey-Bass, San Francisco, CA.

Rivard, L.O.P., 1994, 'A review of writing to learn in science: Implications for practice and research', Journal of Research in Science Teaching 31(9), 969-983.

Street, B., 1997, 'Academic literacies and the new orders': Implications for research and practice', English in education 31(3), 45-59.

Street, B., 2004, 'Academic literacies and the "new orders": Implications for research and practice in student writing in higher education', Learning and Teaching in the Social Sciences 1(1), 9-20. https://doi.org/10.1386/Itss.1.1.9/0

Strevens, P., 1988, 'ESP after twenty years: A reappraisal', in M. Tickoo (ed.), ESP: State of the art, pp. 1-13, SEAMEO Regional Language Centre, Singapore.

Thesen, L. \& Van Pletzen, E., 2006, Academic literacy and the languages of change, Continuum, London.

Tsui, L., 2002, 'Fostering critical thinking through effective pedagogy', The Journal of Higher Education 73(6), 740-763. https://doi.org/10.1353/jhe.2002.0056

Van Rensburg, W., 2011, 'The discourse of selfhood: Students negotiating their academic identities in a writing centre', in A. Archer \& R. Richards (eds.), Changing spaces, pp. 59-72, African Sun Media, Stellenbosch.

Young, A., 2003, 'Writing across and against the curriculum', College Composition and Communication 54(3), 472-485. https://doi.org/10.2307/3594174 